\title{
Article \\ Correlational Analysis of Agronomic and Seed Quality Traits in Camelina sativa Doubled Haploid Lines under Rain-Fed Condition
}

\author{
Jahad Soorni ${ }^{1, *(\mathbb{D})}$, Zahra-Sadat Shobbar ${ }^{1} \mathbb{D}$, Danial Kahrizi ${ }^{2}$, Federica Zanetti ${ }^{3} \mathbb{D}$, Kaveh Sadeghi ${ }^{4}$, \\ Sara Rostampour ${ }^{5}$, Péter Gergó Kovács ${ }^{6}$, Attila Kiss ${ }^{7}$ and Iman Mirmazloum ${ }^{8, *(D)}$
}

Citation: Soorni, J.; Shobbar, Z.-S.; Kahrizi, D.; Zanetti, F.; Sadeghi, K.; Rostampour, S.; Kovács, P.G.; Kiss, A.; Mirmazloum, I. Correlational Analysis of Agronomic and Seed Quality Traits in Camelina sativa Doubled Haploid Lines under Rain-Fed Condition. Agronomy 2022, 12, 359. https://doi.org/10.3390/ agronomy12020359

Academic Editor: Søren

Kjærsgaard Rasmussen

Received: 11 January 2022

Accepted: 28 January 2022

Published: 31 January 2022

Publisher's Note: MDPI stays neutral with regard to jurisdictional claims in published maps and institutional affiliations.

Copyright: (C) 2022 by the authors. Licensee MDPI, Basel, Switzerland. This article is an open access article distributed under the terms and conditions of the Creative Commons Attribution (CC BY) license (https:// creativecommons.org/licenses/by/ $4.0 /)$.
1 Department of Systems Biology, Agricultural Biotechnology Research Institute of Iran (ABRII), Agricultural Research, Education and Extension Organization (AREEO), Karaj 41996, Iran; shobbar@abrii.ac.ir

2 Department of Agronomy and Plant Breeding, Faculty of Agriculture, Razi University, Kermanshah 67144, Iran; d.kahrizi@razi.ac.ir

3 Department of Agricultural and Food Sciences, Alma Mater Studiorum-University of Bologna, Viale Fanin 44, 40127 Bologna, Italy; federica.zanetti5@unibo.it

4 Department of Plant Breeding and Biotechnology, Faculty of Plant Production, Gorgan University of Agricultural Sciences and Natural Resources, Gorgan 49189, Iran; ako.sadeghi@yahoo.com

5 School of Computer, Mathematical, Natural Sciences, Morgan State University, Baltimore, MD 21251, USA; saros4@morgan.edu

6 Department of Agronomy, Institute of Agronomy, Hungarian University of Agriculture and Life Sciences, H-2100 Gödöllo, Hungary; kovacs.gergo.peter@uni-mate.hu

7 Agro-Food Science Techtransfer and Innovation Centre, Faculty for Agro-, Food- and Environmental Science, Debrecen University, H-4032 Debrecen, Hungary; attilakiss.eger@gmail.com

8 Department of Plant Physiology and Plant Ecology, Institute of Agronomy, Hungarian University of Agriculture and Life Sciences, Ménesi Str. 44, H-1118 Budapest, Hungary

* Correspondence: j.soorni@sanru.ac.ir (J.S.); mirmazloum.seyediman@uni-mate.hu (I.M.)

Abstract: Camelina (Camelina sativa (L.) Crantz) is an emerging industrial crop from the Brassicaceae family, with its seed oil and cake being used for food, feed, and fuel applications. In this study, the relationships between economically important agronomic traits including seed yield (SY), days to maturity (DM), 1000-seed weight (TSW), seed protein content (PC), seed oil content (OC), and fatty acid composition in 136 doubled haploid (DH) camelina lines were investigated under rain-fed conditions in two consecutive years. There was prominent diversity among the studied DH lines for the agronomic traits such as seed yield, erucic acid, omega3, protein content, etc. Based on the Pearson correlation analysis of the data, SY was positively correlated with DM and OC, and negatively correlated with TSW, PC, and linolenic acid (C18:3) content. The positive relationships of the main characteristics, relevant to industrial applications, suggest the feasibility of developing new higher-yielding camelina cultivars with high seed oil content. The high seed yield of some camelina lines (DH044 and DH075) during the two growing seasons showed the potential of the lines. On the other hand, the contrasting genotypes for key traits in this study promised a favorable source to develop the superior breeding lines with higher seed yield and food/nonfood traits. Therefore, it can be concluded that the diversity of camelina DH lines traits is crucial for developing new cultivars. Furthermore, the present study reports some significant correlations among the DH lines, which may be useful for the current and future camelina breeding program.

Keywords: seed yield components; correlation; oilseed crop; crude protein; fatty acid

\section{Introduction}

Camelina (Camelina sativa (L.) Crantz), a Brassicaceae family member, has a short growth period and is closely related to the model plant Arabidopsis thaliana and Brassica napus [1,2]. Due to the wide portfolio of biobased applications for oilseed crops, the development and evaluation of new genotypes, particularly in emerging oilseed species, 
is an appropriate approach to achieve superior cultivars with improved oil production potential [3,4]. Camelina is an industrial crop that has recently attracted particular attention among researchers and industry worldwide, especially in Canada, the United States, and Europe [5-11].

Camelina seeds' oil content ranges from $30 \%$ to $49 \%$ of their dry weight [12], and is characterized for its high amount of unsaturated fatty acids ( $>90 \%): 14-16 \%$ oleic acid (C18:1), 15-23\% linoleic acid, (C18:2), 31-40\% linolenic acid (C18:3), and 12-15\% eicosenoic acid (C20:1) [13]. Camelina seeds also contain a relatively high level of proteins (23-27\%) [14] making them a potential source of animal feed [15-17]. In addition to its food, feed, and nutritional applications, camelina oil can be used for biofuel production, in particular jet fuel [17].

Camelina was widely grown in Europe and in the south-west of Asia as an oilseed until the last century [18]. The cultivation of camelina diminished due to the emergence of more productive oilseeds. However, the plant is gaining more attention for its nutritional properties such as its protein content and profile [19]. Camelina is currently cultivated in Canada, the United States, Europe, and Russia and is the subject of several breeding programs to enhance its productivity and nutritional properties. It is also considered as an alternative oilseed crop in other regions of the world [8,20-23] where its cultivation management and productivity is under evaluation.

The genome sequence and transcriptome analysis of camelina $(2 n=6 x=42)$ revealed a high degree of similarity in functional genes with the model plant Arabidopsis [24-27], making it plausible to adopt and utilize the results of genetic studies in Arabidopsis to be considered in camelina breeding research and cultivation management [28].

The production of doubled haploid lines (DH) through anther culture is one of the fastest and most efficient approaches for producing high purity cultivars with enhanced traits, which has been well utilized in many plant species [29]. However, there are limited studies in camelina following this approach [30,31]. Although, several studies have been conducted to investigate the seed oil composition of camelina [32-34], the relationships between the seed components and agronomically relevant traits have not been explored or well documented up to now [5].

Having a large number of $\mathrm{DH}$ lines at our disposal, an augmented experimental design was conducted [35] to compare a large number of unreplicated entries, which is typically used in early generations of plant breeding programs [36]. Augmented block design was first proposed by [37] and afterward used and developed further by other researchers in different studies [38-40].

With regard to the fact that the industrialized world increasingly needs oil and oilseed products for food, feed, and fuel industries, the production and evaluation of new genotypes with new oil composition is indispensable for the world oil supply. Consequently, in the present study, the relationships among oil content, protein content, and seed yield with related agronomic traits of the new DH camelina lines grown under rain-fed conditions are presented and discussed.

\section{Materials and Methods}

\subsection{Plant Materials and Experimental Conditions}

For this study, $136 \mathrm{DH}$ lines of camelina derived from 15 different crosses (Figure S1) were produced at Bisetonshafa Co., Kermanshah, Iran using the anther culture technique. The information on the tested DH lines can be accessed in a former published study [31] and is summarized in Supplementary Table S1. The study was carried out under nonirrigated field conditions in the Karaj province (Latitude: $35^{\circ} 50^{\prime} \mathrm{N}$, Longitude: $50^{\circ} 56^{\prime} \mathrm{E}$, Elevation: 1380 m.a.s.l.) of Iran during 2015-2018 growing seasons. The meteorological data of the experimental station during the growing seasons are presented in Supplementary Figure S2. In the semi-arid climate of the experiment location with hot summers and cold winters, precipitation usually begins in October/November and continues until April/May. Soil preparation of the experimental site was performed by a rolling harrow before the 
seed sowing after the harvest of the preceding crop (winter wheat). The seeds were sown manually in November and harvested in May/June. The main soil characteristic of the experimental farm is presented in Supplementary Table S2. The soil texture was categorized to a silt loam according to the USDA soil taxonomy system. The camelina plots were hand-weeded during the growing season and no additional fertilization was applied.

\subsection{Experimental Design}

An augmented randomized complete block design (RCBD) [41] with eight incomplete blocks and three randomly selected check lines (DH010, DH029, and DH136) as controls in each incomplete block was applied for the comparison of the DH lines' performance under field conditions. The experimental design and the position of control lines in different blocks are presented in Figure S3. The seeds of each DH line were sown in rows of $1 \mathrm{~m}$ in length, $20 \mathrm{~cm}$ distance between the rows, and $3 \mathrm{~cm}$ between the DH lines on a row.

\subsection{Morphological Traits Measurement}

The key parameters and industrially important traits such as days to physiological maturation (DM), thousand seed weight (TSW), and seed yields (SY) were recorded. To determine the SY, 10 plants from each plot were hand-harvested, and the mean SY value was recorded as fresh and after oven-drying as dry matter. TSW was determined by counting 1000 seeds using a seed counter Sly-C (CGoldenwall), and recording the seeds' weight. The number of days from sowing to physiological maturity in each plot was recorded when at least $50 \%$ of pods turned brown in color [42].

\subsection{Oil and Protein Content and Free Fatty Acids Measurement}

The oil content was measured at the National Institute of Genetic Engineering and Biotechnology (NIGEB), Tehran, Iran according to the methods of Bansal et al., [43] with minor modifications. Briefly, the seeds of the DH camelina lines were ground manually in mortar and pestle of which $5 \mathrm{~g}$ was subjected for extraction using Soxhlet extractor and $\mathrm{n}$ hexane as solvent for eight hours. The oil soluble fatty acids were saponified under vacuum after removing the solvent in a vacuum evaporator according to Lopez-Martinez et al. [44] in triplicate. The fatty acids were then methylated according to Lepage and Roy's method [45]. The methyl derivatives of fatty acids were isolated after cooling to room temperature and solvent removal for gas chromatography (GC) analysis. The isolation and identification of various fatty acids were carried out using a Varian CP 3800 GC fitted with a flame ionization detector (FID) equipped with a polar silica column $(60 \mathrm{~m} \times 0.25 \mathrm{~mm}$ i.d., $0.2 \mu \mathrm{m})$. Helium was delivered at a flow rate of $1 \mathrm{~mL} / \mathrm{min}$ as a carrier gas. The components of each sample were analyzed using Workstation software (V 6.4). The oil content of seed samples was calculated and reported based on their dry weight percent and fatty acids content based on total oil content by comparing their peak area with standard samples (Sigma-Aldrich, St. Louis, MO, USA). The crude protein content was determined in a Kjeldahl method (Kjeltec analyser unit 2300, Sweden) and calculated by using the conversion factor of 6.25 for nitrogen content [46].

\subsection{Statistical Analysis}

The statistical analysis, including Analysis of Variance, Pearson correlation, principal component analysis (PCA) biplot, and heat map graphs, was carried out by using augmented RCBD [41], ggpubr, ggplot2, ggpmisc, and gplots packages, respectively, in R environment ver. 4.1.2 and Rstudio ver. 2021.09.0 + 351 software. The significant correlation coefficients with a $p$-value lower than 0.05 were presented in the correlation graph using asterisks. For standardization of different variables in the heatmap, Z-score standardization was applied. 


\section{Results}

\subsection{Comparison of Plant Grwoth and Fatty Acids in DH Lines of Camelina}

In this study, the diversity and relationships between the seed quality and important agronomical traits of camelina were considered for analysis under rain-fed conditions. Promising and significant diversity for both seed quality and morphological traits were observed among the studied DH camelina lines (Table 1). In detail, camelina seed yield, seed weight, maturity time, protein, and oil content and oil composition were significantly different at 0.01 level of probability in the $\mathrm{DH}$ and check lines under two cropping seasons (Table 1). In this regard, the two more important fatty acids in camelina named erucic acid and omega 3 content, were also significantly different between the surveyed lines during the two years, which can be used to develop new camelina cultivars with a lower level of unfavorable erucic acid (Table 1).

Table 1. Analysis of variation in surveyed camelina traits during two consecutive growing seasons.

\begin{tabular}{|c|c|c|c|c|c|c|c|c|c|c|c|c|c|c|c|c|c|c|c|c|c|c|c|c|c|c|c|}
\hline Source & $\underset{\oplus}{\sigma}$ & $\stackrel{\rho}{\stackrel{\rho}{0}}$ & $\stackrel{\rho}{\oplus}$ & $\stackrel{\circ}{0}$ & $\stackrel{\Omega}{\sigma}$ & $\stackrel{\rho}{\infty}$ & $\stackrel{\rho}{\infty}$ & $\underset{\infty}{\stackrel{\infty}{\sim}}$ & $\underset{\substack{\infty \\
i}}{\rho}$ & $\begin{array}{l}\text { No } \\
\stackrel{0}{0}\end{array}$ & N̦ & N & స్. & $\underset{N}{N}$ & $\stackrel{N}{N}$ & $\underset{N}{N}$ & N & $\underset{\mathbb{N}}{\stackrel{N}{\oplus}}$ & 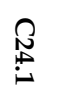 & $\stackrel{n}{T}$ & 秀 & 马 & ○ & 5 & ত & ث્ & 2 \\
\hline \multicolumn{28}{|c|}{ 1st Year } \\
\hline Block & 7 & $* *$ & ns & ns & ns & ns & ns & ns & ns & * & ns & ns & $* *$ & ns & ns & ns & ns & ns & ns & ns & ns & ns & ns & $* *$ & ns & ns & ns \\
\hline $\begin{array}{l}\text { Check } \\
\text { Lines }\end{array}$ & 2 & $*$ & $* *$ & $* *$ & ns & $* *$ & $* *$ & $* *$ & $* *$ & $* *$ & $* *$ & $* *$ & $* *$ & $* *$ & $* *$ & $* *$ & $* *$ & $* *$ & $* *$ & $* *$ & $* *$ & $* *$ & $* *$ & $* *$ & $* *$ & $* *$ & $* *$ \\
\hline $\begin{array}{l}\mathrm{DH} \\
\text { Lines }\end{array}$ & 135 & ns & ns & $* *$ & $*$ & $* *$ & $* *$ & $* *$ & $* *$ & $* *$ & $* *$ & $* *$ & $* *$ & $* *$ & $* *$ & $* *$ & $* *$ & $* *$ & $* *$ & $* *$ & $* *$ & $* *$ & $* *$ & $* *$ & $* *$ & $* *$ & $* *$ \\
\hline \multicolumn{28}{|c|}{ 2nd Year } \\
\hline Block & 7 & ns & ns & ns & ns & ns & ns & ns & ns & ns & ns & ns & ns & ns & ns & ns & ns & ns & $*$ & ns & ns & ns & $* *$ & ns & ns & ns & ns \\
\hline $\begin{array}{l}\text { Check } \\
\text { Lines }\end{array}$ & 2 & ns & ns & $* *$ & ns & ns & $* *$ & $* *$ & $* *$ & $* *$ & $* *$ & $* *$ & $* *$ & $* *$ & $* *$ & ns & $* *$ & ns & * & $* *$ & $* *$ & $* *$ & $* *$ & $* *$ & $* *$ & $* *$ & $* *$ \\
\hline $\begin{array}{c}\text { DH } \\
\text { Lines }\end{array}$ & 135 & ns & ns & $* *$ & ns & $* *$ & $* *$ & $* *$ & $* *$ & $* *$ & $* *$ & $* *$ & * & ns & $* *$ & $* *$ & $* *$ & ns & $*$ & $* *$ & ns & $* *$ & $* *$ & $* *$ & $* *$ & $* *$ & $* *$ \\
\hline
\end{tabular}

Adjusted average seed yield (SY) of the $136 \mathrm{DH}$ lines was $1149 \mathrm{~kg} \mathrm{ha}^{-1}$ in the first year and $1208 \mathrm{~kg} \mathrm{ha}^{-1}$ in the second year with a range between $853 \mathrm{~kg}$ and $813 \mathrm{~kg} \mathrm{ha}^{-1}$, respectively (Table 2).

Interestingly, there was significant diversity in $\alpha$-linolenic acid content along with seed yield within the tested DH camelina lines in two consecutive growing seasons (Table 1). The $\alpha$-linolenic acid (C18:3); one of the principal fatty acids in camelina oil, showed significant changes among the genotypes in the present study and ranged between $30.04-34.98 \%$, and $30.05-34.16 \%$ in the first and second years, respectively (Table 2). In general, the seed quality was not significantly affected in two growing seasons. The average content of saturated fatty acids (SFA), monounsaturated fatty acids (MUFA) and polyunsaturated fatty acids (PUFA) of camelina lines were, respectively, $10.95 \pm 0.78,34.11 \pm 0.94$, and 54.89 percent with a range between 4.01, 4.49, and 5.27 percent in the first year and $10.97 \pm 0.71,34.15 \pm 0.90$, and $54.84 \pm 0.97$ percent with a range between $4.03,4.83$, and 5.41 percent in the second year (Table 2). 
Table 2. Overview of variation in the surveyed parameters of DH camelina lines included in the study.

\begin{tabular}{|c|c|c|c|c|c|c|c|c|}
\hline \multirow{2}{*}{ Parameters } & \multicolumn{2}{|c|}{ Minimum } & \multicolumn{2}{|c|}{ Maximum } & \multicolumn{2}{|c|}{ Mean \pm SD } & \multicolumn{2}{|c|}{$\mathrm{CV}$} \\
\hline & 1st Year & 2nd Year & 1st Year & 2nd Year & 1st Year & 2nd Year & 1st Year & 2nd Year \\
\hline C12:0 (\%) & 0.04 & 0.04 & 0.07 & 0.07 & $0.05 \pm 0.01$ & $0.05 \pm 0.01$ & 7.1 & 11.6 \\
\hline C14:0 (\%) & 0.08 & 0.08 & 0.13 & 0.13 & $0.10 \pm 0.01$ & $0.10 \pm 0.01$ & 7.2 & 7.0 \\
\hline C16:0 (\%) & 3.53 & 3.59 & 6.8 & 6.58 & $5.69 \pm 0.55$ & $5.70 \pm 0.49$ & 3.0 & 3.4 \\
\hline C16:1 (\%) & 0.16 & 0.15 & 0.22 & 0.22 & $0.19 \pm 0.01$ & $0.19 \pm 0.01$ & 3.6 & 4.4 \\
\hline C18:0 (\%) & 1.52 & 1.51 & 3.39 & 3.03 & $2.44 \pm 0.33$ & $2.42 \pm 0.03$ & 2.3 & 3.5 \\
\hline $\mathrm{C} 18: 1(\%)$ & 13.36 & 13.45 & 18.26 & 17.75 & $15.53 \pm 0.97$ & $15.52 \pm 0.93$ & 0.5 & 1.4 \\
\hline C18:2 (\%) & 15.97 & 16.42 & 22.13 & 21.91 & $19.18 \pm 1.29$ & $19.22 \pm 1.24$ & 0.5 & 1.6 \\
\hline C18:3 (\%) & 30.04 & 30.05 & 34.98 & 34.16 & $32.28 \pm 0.96$ & $32.14 \pm 0.91$ & 0.5 & 0.5 \\
\hline C20:0 (\%) & 1.45 & 1.53 & 2.69 & 2.77 & $1.92 \pm 0.22$ & $1.94 \pm 0.21$ & 2.5 & 3.6 \\
\hline C20:1 (\%) & 13.34 & 13.52 & 16.29 & 16.12 & $14.61 \pm 0.55$ & $14.69 \pm 0.55$ & 0.5 & 0.8 \\
\hline C20:2 (\%) & 1.14 & 1.21 & 1.82 & 1.78 & $1.51 \pm 0.15$ & $1.51 \pm 0.12$ & 3.9 & 3.0 \\
\hline C20:3 (\%) & 0.94 & 1.03 & 1.62 & 1.50 & $1.22 \pm 0.11$ & $1.24 \pm 0.09$ & 3.1 & 4.7 \\
\hline C22:0 (\%) & 0.39 & 0.42 & 0.61 & 0.65 & $0.48 \pm 0.04$ & $0.51 \pm 0.04$ & 4.4 & 6.1 \\
\hline C22:1 (\%) & 2.50 & 2.39 & 3.71 & 3.49 & $3.01 \pm 0.23$ & $3.05 \pm 0.23$ & 1.7 & 4.0 \\
\hline $\mathrm{C} 22: 2(\%)$ & 0.13 & 0.15 & 0.23 & 0.26 & $0.19 \pm 0.02$ & $0.21 \pm 0.02$ & 4.5 & 5.4 \\
\hline C22:3 (\%) & 0.37 & 0.39 & 0.63 & 0.65 & $0.50 \pm 0.06$ & $0.53 \pm 0.05$ & 2.8 & 4.0 \\
\hline C24:0 (\%) & 0.20 & 0.18 & 0.35 & 0.32 & $0.27 \pm 0.03$ & $0.25 \pm 0.03$ & 4.4 & 9.1 \\
\hline C24:1 (\%) & 0.60 & 0.53 & 0.92 & 0.90 & $0.78 \pm 0.07$ & $0.70 \pm 0.08$ & 2.4 & 5.5 \\
\hline SFA (\%) & 8.90 & 9.04 & 12.93 & 13.05 & $10.95 \pm 0.78$ & $10.97 \pm 0.71$ & 1.7 & 1.8 \\
\hline MUFA (\%) & 32.05 & 32.13 & 36.88 & 36.62 & $34.11 \pm 0.94$ & $34.15 \pm 0.90$ & 0.4 & 1.7 \\
\hline PUFA (\%) & 52.29 & 51.70 & 57.7 & 56.97 & $54.89 \pm 1.06$ & $54.84 \pm 0.97$ & 0.3 & 0.8 \\
\hline $\mathrm{OC}(\%)$ & 32.76 & 33.56 & 38.37 & 38.99 & $35.91 \pm 1.25$ & $36.24 \pm 1.20$ & 0.3 & 0.5 \\
\hline PC $(\%)$ & 25.66 & 25.25 & 30.47 & 29.99 & $27.76 \pm 0.91$ & $27.36 \pm 0.89$ & 0.3 & 0.6 \\
\hline DM (day) & 144 & 148 & 218 & 221 & $167 \pm 11.8$ & $168 \pm 11.4$ & 1.5 & 2.4 \\
\hline TSW (g) & 0.60 & 0.69 & 1.47 & 1.52 & $1.06 \pm 0.19$ & $1.12 \pm 0.18$ & 6.8 & 4.7 \\
\hline SY $\left(\mathrm{kg} \mathrm{ha}^{-1}\right)$ & 783 & 831 & 1636 & 1644 & $1149 \pm 194$ & $1208 \pm 187$ & 1.0 & 4.1 \\
\hline
\end{tabular}

SFA $=$ Saturated Fatty Acid, MUFA $=$ Monounsaturated Fatty Acids, PUFA $=$ Polyunsaturated Fatty Acids $\mathrm{OC}=$ Oil Content, $\mathrm{PC}=$ Protein Content, $\mathrm{DM}=$ Days to Maturity, $\mathrm{TSW}=$ Thousand Seed Weight, $\mathrm{SY}=$ Seed Yield SFA includes C12:0, C14:0, C16:0, C18:0, C20:0, C22:0, and C24:0. MUFA includes C16:1, C18:1, C20:1, C22:1, and C24:1. PUFA includes C18:2, C18:3, C20:2, C20:3, C22:2, and C22:3. $\mathrm{n}=136$.

A significant difference was detected between the $\mathrm{DH}$ lines for the average of the traits in the two studied growing seasons (Table 1). The adjusted average of palmitic acid (C16:0), oleic acid (C18:1), linoleic acid (C18:2), linolenic acid (C18:3), erucic acid (C22:1), SFA, MUFA, OC, PC, DM, TSW, and SY showed that there was a pronounced diversity for future breeding programs (Figure 1). There were some contrasting genotypes for oil compositions, protein and oil content, seed yield and weight, and early/delay maturity habit, which are useful in omics studies to unravel the genetic mechanisms of these traits. This remarkable diversity among the DH lines perhaps are due to the different parental origin of these lines (Figure S1 and Table S1). 

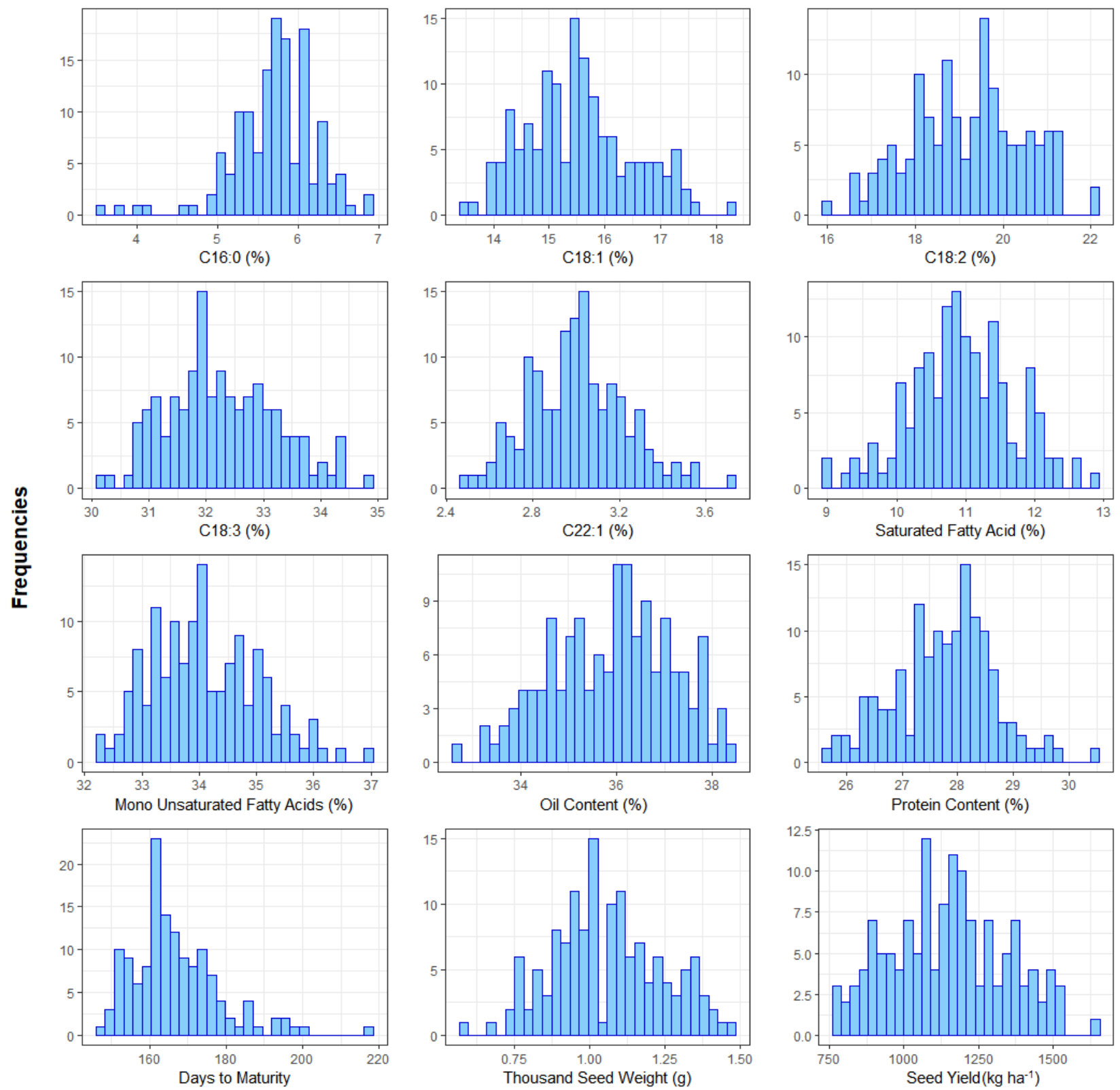

Figure 1. Frequency distribution of selected traits in camelina DH lines.

\subsection{Correlation Analysis}

The Pearson correlation coefficient among the selected traits is shown in Figure 2.

The results showed that there were robust correlations between SY with OC and DM in the biennial average (Figure 2). On the other hand, oil and protein contents had a negative correlation $(\mathrm{r}=-0.75)$. The DM negatively correlated with TSW, PC, C16:1, C18:3, and C22:1. Interestingly, linolenic acid (C18:3), a nutritional factor, showed a negative correlation $(\mathrm{r}=-0.36)$ with erucic acid $(\mathrm{C} 22: 1)$ as an anti-nutrition factor. 


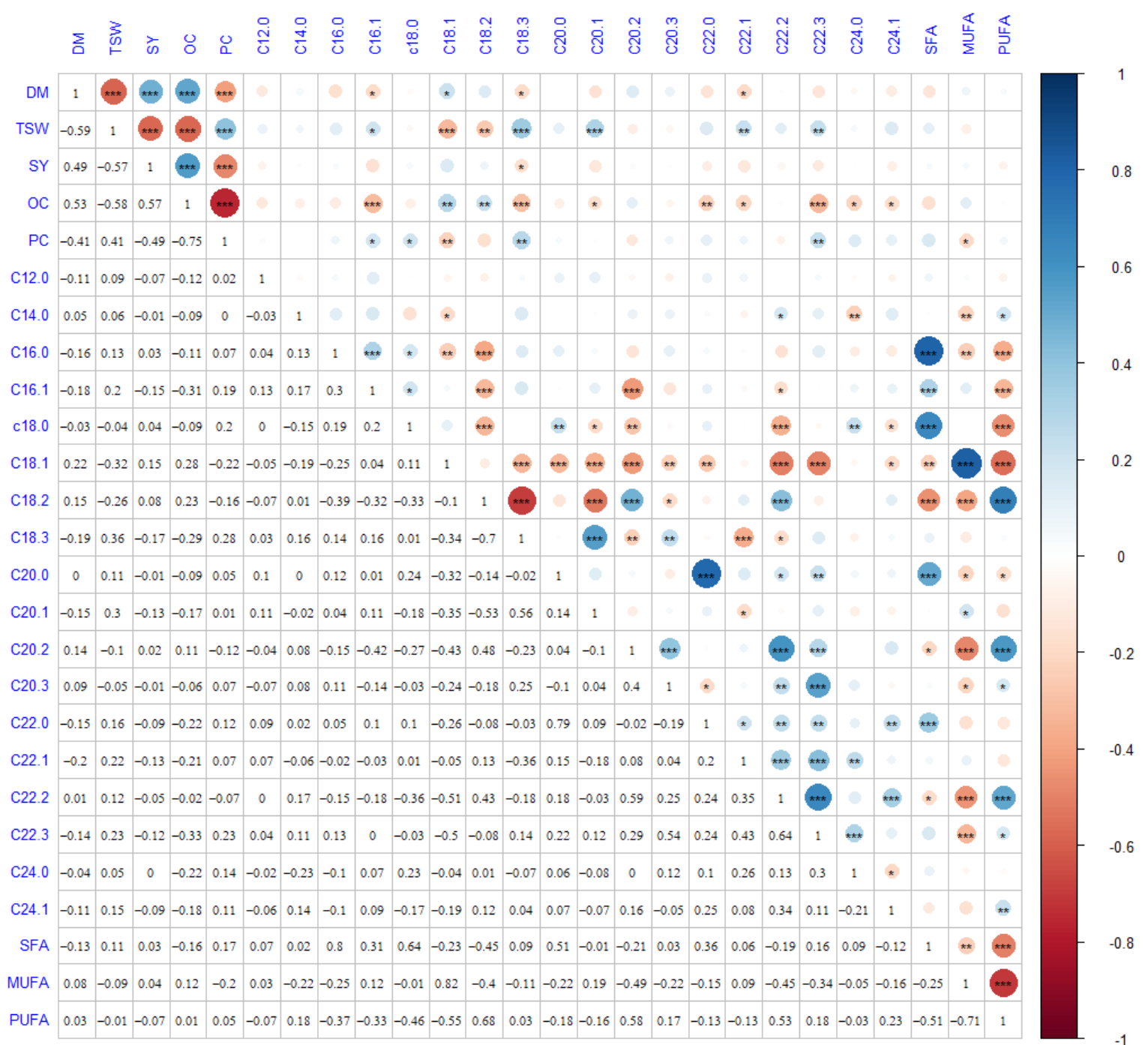

Figure 2. Heatmap correlations of the different characters of 136 camelina DH lines. Ns: $p>0.05$; ${ }^{*}: p \leq 0.05 ;{ }^{* *}: p \leq 0.01 ;{ }^{* *}: p \leq 0.001$. The different colors (Red = negative correlations, Blue $=$ positive correlations) in the scale, as well as the numbers on the right end side of the figure show the Pearson correlation coefficient.

Generally, the DH camelina lines characterized by small seed size such as DH031 had less protein content but higher seed yield and oil content in the seeds (Figures 2 and 3).

The graphical representation of the data as a clustered heat map can simplify the presentation of variations and relationships between seed composition [8] and the agronomical traits of camelina (Figure 3). The obvious negative relationship between MUFA and PUFA is shown in Figure 3. The negative relationship between MUFA and PUFA was also reported by Krzyżaniak et al. [8] in 10 spring camelina genotypes grown in Poland. DH031 had the highest DM associated with low SFA and a fairly high amount of C18:1 and C18:2 rather than the spring biotypes (Figure 3). This result confirmed that SFA can be reduced in late maturity genotypes. Furthermore, some of the lines such as DH042 were characterized by a low level of long-chain fatty acids $(C \geq 22)$ associated with a high level of long-chain fatty acids ( $16 \geq \mathrm{C} \geq 22$ ) (Figure 3 ). 


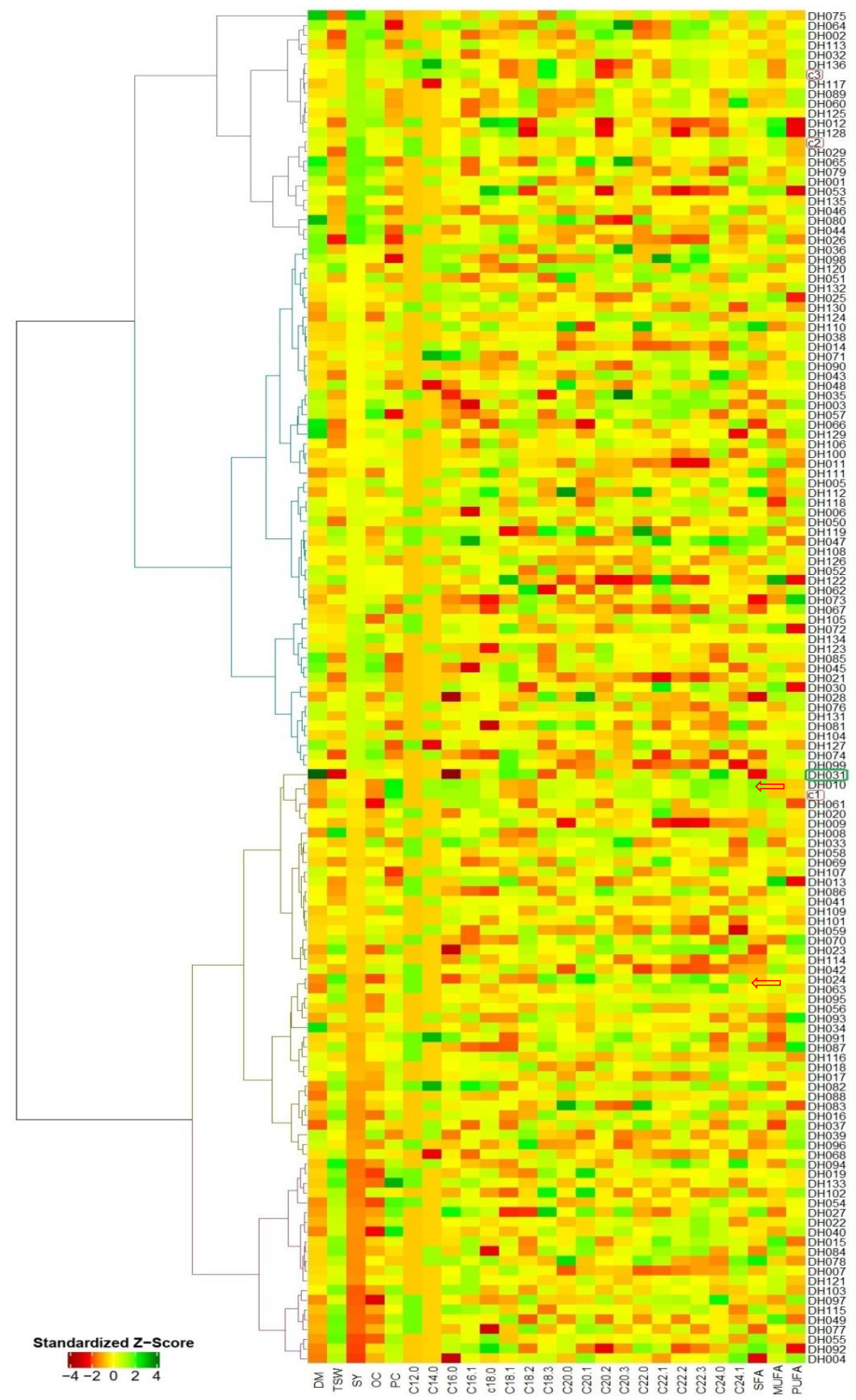

Figure 3. Heat map with a dendrogram of the measured traits in the $136 \mathrm{DH}$ lines of camelina. In each column, the colors represent Z-score standardization of the data. DH lines showed in rows and surveyed traits are in columns. DM = Days to Maturity, TSW = Thousand Seed Weight, SY = Seed Yield, OC = Oil Content, PC = Protein Content, SFA = Saturated Fatty Acid, MUFA = Monounsaturated Fatty Acids, PUFA = Polyunsaturated Fatty Acids. c1, c2, and c3 were the control genotypes.

A PCA-based biplot is a powerful technique for the visualization of genotypes and variables simultaneously. PCA for the surveyed traits showed that the first two components 
explained $35 \%$ of the total variation in the averages of the two cropping seasons (Figure 4 ). The PCA biplot revealed a remarkable diversity among the $\mathrm{DH}$ lines and grouped the lines according to their parental crosses (Figure 4). The first principal component (PC1) had a negative correlation with the DM, SY, OC, MUFA, PUFA, C18:1, C18:2, and C20:2 traits (Figure 4). This means that those lines that showed a negative PC1, had higher values for the analyzed traits.

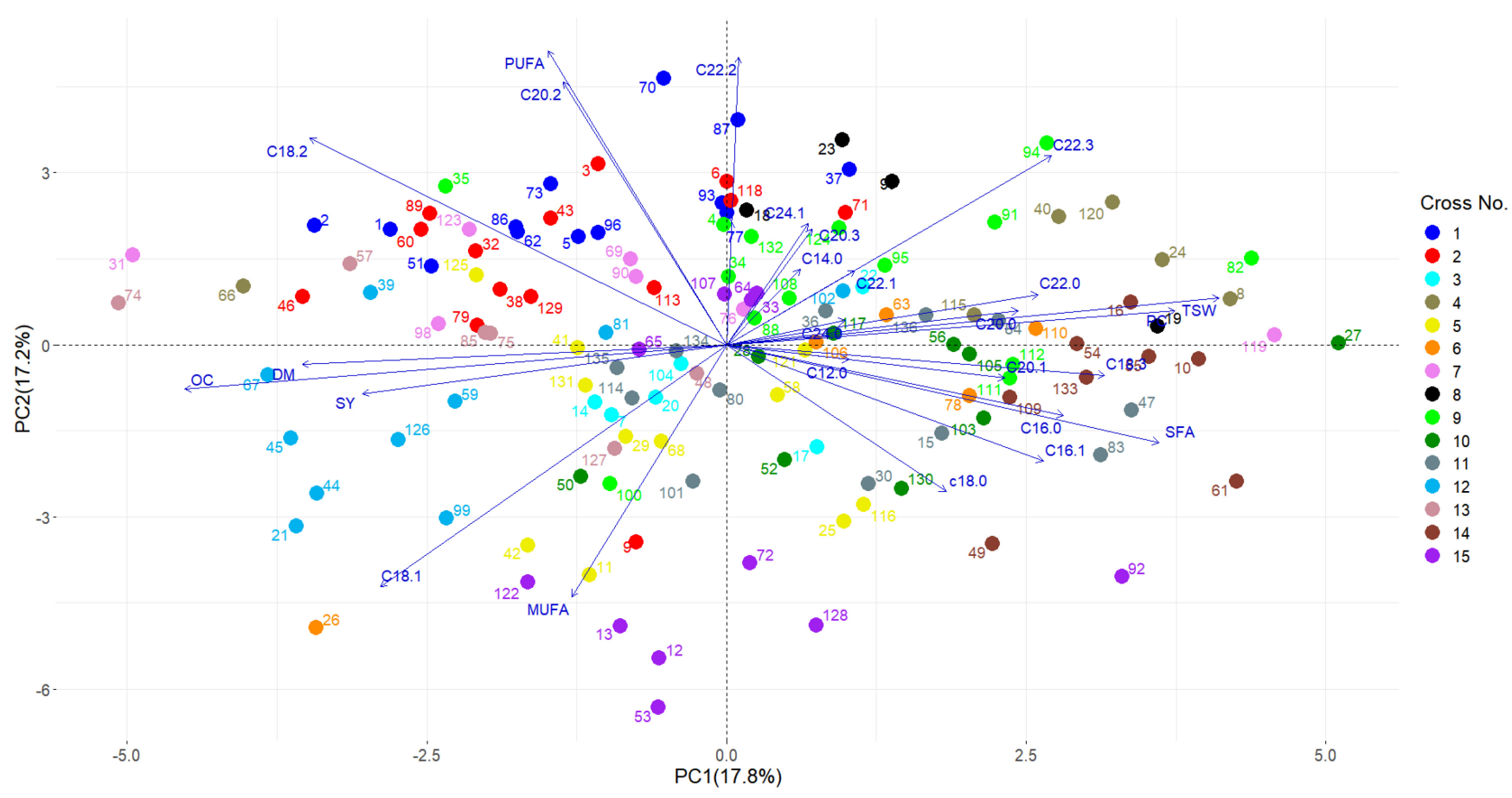

Figure 4. Biplot of genotypes according to PC1 and PC2 of measured traits. The DH lines (showed with the numbers in biplot) derived from each of the 15 different crosses are presented with a differentiated color.

\section{Discussion}

The confirmed superiority of camelina compared with oilseed rape as well as Brassica carinata and B. juncea, means that it is much more resilient to environmental stresses, which leads to its higher performance under rain-fed conditions [47]. Camelina seed yield and quality widely varied across the $\mathrm{DH}$ lines in the present study during two cropping seasons. Similar findings were recently reported by Zanetti et al. [48] and Leclere et al. [49] in different genotypes of camelina. In this regard, Krzyżaniak et al. [8] reported much larger diversity among growing seasons for yields ranging from 1.33 in 2016 to $2.55 \mathrm{Mg} \mathrm{ha}^{-1}$ in 2018 from the plants cultivated in Poland. Similar results for SY were reported by Zanetti et al. [5] in Poland, Italy, Greece, and Canada, by Kurasiak-Popowska et al. [50] and Krzyżaniak et al. [8] in the Ukraine, and by Załuski et al. [51] in Poland. Therefore, camelina SY can be significantly enhanced under favorable environmental conditions. These results showed that despite camelinas' environmental suitability, the SY can be considerably increased under optimum conditions. The findings of this study showed that the environmental conditions may change the ranking of $\mathrm{DH}$ lines as well as in the check lines; therefore, a multi-year average of yield reporting should be considered.

Camelina is a drought and frost tolerant oilseed crop [52], making it a smart choice for producing high-quality oil under rain-fed conditions in areas with adequate precipitation in fall and spring. Obeng et al. [53] suggested a delay in planting date to early-to mid-April for optimum spring camelina seed yield where the saturated fatty acid (SFA) concentration was also increased compared with the mid-March planting date on non-irrigation farms of western Kansas. The mid-March planting date enhanced the oil content and quality 
by increasing PUFA and ALA concentrations. Our studied $136 \mathrm{DH}$ lines derived from 15 different crosses helped us to find out the relationships between the seed yield and oil quality as a key factor to achieve high yielding cultivars with a favorable oil quality under rain-fed conditions. It is also noteworthy to mention the effect of maturation habitat as well as climatic conditions that may significantly affect the oil quality in oilseed crops $[54,55]$. Among our results there were robust correlations between SY and OC, and SY and DM (Figure 3). Therefore, it is possible to highlight that the late-ripening genotypes can produce higher seed yields with consequent higher oil content. This can be simply the consequence of a longer growth period and higher photosynthate remobilization rate during the last part of the growth cycle. The late ripening is one of the most important agronomic traits and is mostly associated to the winter biotype [56].

Seed quality, especially the fatty acid profile, is an important aspect in camelina production. Although the polyunsaturated fatty acids (PUFAs) with double bonds are not generally desirable for biodiesel, they are very advantageous for industrial applications [57]. The observed diversity among the studied lines of our camelina plants can be an attractive phenomenon for classical breeding and to find functional molecular markers for genotypes selection. The results of reported camelina genetic diversity would be of high interest and crucial for future breeding programs [58].

In a study reported by Zubr [59], the variation in quality of camelina seeds was partly claimed to be due to the genotype's diversity among the studied seven summer varieties and is mainly linked to the combined effects of the climatic and soil conditions, which is in contrast to our observations where the diverse qualitative traits were identified in genotypes grown in the same experimental conditions. The negative correlation of oil and protein content of the seed $(\mathrm{r}=-0.75)$ was also observed in camelina by $[5,8]$.

In a two-year experiment [54] reporting fatty acid compositions of 66 spring and 9 winter biotypes of camelina in Poland under field conditions, significant differences between the spring and winter cultivars were observed but with no differences among the same samples between the growing seasons (2016-2017). For example, the linoleic acid contents in spring and winter biotypes were different (14\% and $16 \%$, respectively), while there was no significant difference in $\alpha$-linolenic acid content (37-38\%). In our study however, DH031 as a winter biotype, had a higher level of C18:1 and C18:2 and lower level of C18:3, but this behavior was observed in some spring lines, such as DH067, as well. DH031, which is a winter type, had favorable unsaturated fatty acid, but, needing vernalization, must be sowed in fall in regions with low temperatures in the winter. Therefore, there were no significant differences in the fatty acid profile between the summer and winter biotypes of camelina grown in greenhouse conditions [60]. The fatty acid composition of different camelina lines was stable also in the work of Augustin et al. [61], comparing both greenhouse and field conditions. The existing diversity of the obtained results of camelina research worldwide is strong evidence for a promising future of this minor oilseed crop as a particular candidate suitable for the concept of bio-economy [62].

Delayed sowing of spring camelina in Nevada negatively affected oil content, seed yield, and biodiesel production, and the authors claimed that a delay in sowing seed in semi-arid agroecosystems might be a challenge [42]. Furthermore, Righini et al. [22] also suggested shifting the sowing time of camelina from spring to autumn to increase the oil quality of seeds for biobased applications. Our results illustrated that spring-type camelinas can be successfully cultivated in fall under the rain-fed conditions of Iran. Since cultivation in spring needs irrigation to produce a satisfactory yield, we suggest sowing camelina exactly before the first rain in the fall under Iranian climatic conditions.

\section{Conclusions}

The increasing interest in camelina cultivation and research is due to its specific fatty acid profile, particularly in relation to the high level of omega- 3 when compared to other oilseed crops. In this study, in order to compare the seed yield and important industrial and agronomical characteristics, doubled haploid lines were cultivated under field condition. 
In general, the results of this study showed that, despite the limited availability of cultivars and breeding lines of camelina in many regions of the world, the studied lines had a very good diversity, which could be used for introducing suitable cultivars in different regions of the world. Furthermore, the use of DH camelina lines in future breeding programs will promote the industrial interests since cultivars with higher oil, higher protein content, higher essential fatty acids, and lower erucic acid might be easily selected. Therefore, different camelina lines might undertake different pathways for fatty acid production as a result of doubled haploidy. The presented work can be considered for the future research on identifying the linkage between differentially expressed genes and phytochemical and agronomical traits that are of high interest for camelina breeding.

Supplementary Materials: The following supporting information can be downloaded at: https: / / www.mdpi.com/article/10.3390/agronomy12020359/s1, Figure S1: Proportion of the DH lines derived from each cross in $136 \mathrm{DH}$ lines. Figure S2: Main meteorological data (mean air temperature and total precipitation) for Karaj station during 2015-2018. Figure S3: Augmented design for assessment of the $136 \mathrm{DH}$ lines. Table S1: List of camelina cultivars used as parents in the crosses for production of DH lines. Table S2: Soil characteristics of the experimental site taken from 0-30 cm in the two different cropping years.

Author Contributions: Conceptualization, J.S. and Z.-S.S.; methodology, J.S., F.Z. and S.R.; software, J.S. and K.S.; validation, Z.-S.S., J.S. and I.M.; formal analysis, J.S., F.Z. and I.M.; investigation, J.S., D.K., S.R. and K.S.; resources, Z.-S.S., P.G.K. and I.M.; data curation, J.S. and D.K.; writing-original draft preparation, J.S., A.K. and I.M.; writing—review and editing, Z.-S.S., F.Z. I.M., A.K. and P.G.K.; visualization, J.S.; funding acquisition, P.G.K. All authors have read and agreed to the published version of the manuscript.

Funding: This work was supported by Iran's National Elites Foundation (INEF) (grant number: 970061). The APC was funded by the Hungarian University of Agriculture and Life Sciences (MATE).

Institutional Review Board Statement: Not applicable.

Informed Consent Statement: Not applicable.

Data Availability Statement: Not applicable.

Acknowledgments: J.S. is thankful to Christina Eynck from Agriculture and Agri-Food Canada for the valuable editing of the manuscript. In addition, to Plant Gene Resources of Canada, Science and the Technology Branch of Agriculture and Agri-Food Canada/Government of Canada and to the University of Thessaly, Greece for the donation of some parents of the camelina DH lines.

Conflicts of Interest: The authors declare no conflict of interest.

\section{References}

1. Vollmann, J.; Eynck, C. Camelina as a sustainable oilseed crop: Contributions of plant breeding and genetic engineering. Biotechnol. J. 2015, 10, 525-535. [CrossRef] [PubMed]

2. Kawall, K. Genome-edited Camelina sativa with a unique fatty acid content and its potential impact on ecosystems. Environ. Sci. Eur. 2021, 33, 38. [CrossRef]

3. White, G.; Gardner, J.; Cook, C. Biodiversity for industrial crop development in the United States. Ind. Crops Prod. 1994, 2, $259-272$. [CrossRef]

4. Kon'Kova, N.; Shelenga, T.; Gridnev, G.; Dubovskaya, A.; Malyshev, L. Stability and Variability of Camelina sativa (L.) Crantz Economically Valuable Traits in Various Eco-Geographical Conditions of the Russian Federation. Agronomy 2021, 11, 332. [CrossRef]

5. Zanetti, F.; Eynck, C.; Christou, M.; Krzyżaniak, M.; Righini, D.; Alexopoulou, E.; Stolarski, M.J.; van Loo, E.N.; Puttick, D.; Monti, A. Agronomic performance and seed quality attributes of Camelina (Camelina sativa L. crantz) in multi-environment trials across Europe and Canada. Ind. Crops Prod. 2017, 107, 602-608. [CrossRef]

6. Leclère, M.; Loyce, C.; Jeuffroy, M.-H. Growing camelina as a second crop in France: A participatory design approach to produce actionable knowledge. Eur. J. Agron. 2018, 101, 78-89. [CrossRef]

7. Horvath, D.; Anderson, J.V.; Chao, W.S.; Zheng, P.; Buchwaldt, M.; Parkin, I.A.P.; Dorn, K. Genes associated with chloroplasts and hormone-signaling, and transcription factors other than CBFs are associated with differential survival after low temperature treatments of Camelina sativa biotypes. PLoS ONE 2019, 14, e0217692. [CrossRef] 
8. Krzyżaniak, M.; Stolarski, M.J.; Tworkowski, J.; Puttick, D.; Eynck, C.; Załuski, D.; Kwiatkowski, J. Yield and seed composition of 10 spring camelina genotypes cultivated in the temperate climate of Central Europe. Ind. Crops Prod. 2019, 138, 111443. [CrossRef]

9. Martin, S.L.; Lujan-Toro, B.E.; Sauder, C.A.; James, T.; Ohadi, S.; Hall, L.M. Hybridization rate and hybrid fitness for Camelina microcarpa Andrz. ex DC (\$) and Camelina sativa (L.) Crantz(Brassicaceae) (o ). Evol. Appl. 2018, 12, 443-455. [CrossRef]

10. Zhang, C.-J.; Auer, C. Overwintering assessment of camelina (Camelina sativa) cultivars and congeneric species in the northeastern US. Ind. Crops Prod. 2019, 139, 111532. [CrossRef]

11. Anderson, J.V.; Neubauer, M.; Horvath, D.P.; Chao, W.S.; Berti, M.T. Analysis of Camelina sativa transcriptomes identified specific transcription factors and processes associated with freezing tolerance in a winter biotype. Ind. Crops Prod. 2021, 177, 114414. [CrossRef]

12. Choi, S.-H.; Park, N.; Lee, K.-Y.; Missaoui, A.M.; Lee, G.-J. Novel genes in response to varying water deficit in oil crop Camelina sativa. Euphytica 2019, 215, 86. [CrossRef]

13. Berti, M.; Gesch, R.; Eynck, C.; Anderson, J.; Cermak, S. Camelina uses, genetics, genomics, production, and management. Ind. Crops Prod. 2016, 94, 690-710. [CrossRef]

14. Walia, M.K.; Wells, M.S.; Cubins, J.; Wyse, D.; Gardner, R.D.; Forcella, F.; Gesch, R. Winter camelina seed yield and quality responses to harvest time. Ind. Crops Prod. 2018, 124, 765-775. [CrossRef]

15. Brock, J.R.; Dönmez, A.A.; Beilstein, M.A.; Olsen, K.M. Phylogenetics of Camelina Crantz. (Brassicaceae) and insights on the origin of gold-of-pleasure (Camelina sativa). Mol. Phylogenetics Evol. 2018, 127, 834-842. [CrossRef] [PubMed]

16. Lawrence, R.D.; Anderson, J.L. Ruminal degradation and intestinal digestibility of Camelina meal and carinata meal compared with other protein sources. Prof. Anim. Sci. 2018, 34, 10-18. [CrossRef]

17. Martinez, S.; Alvarez, S.; Capuano, A.; Delgado, M.D.M. Environmental performance of animal feed production from Camelina sativa (L.) Crantz: Influence of crop management practices under Mediterranean conditions. Agric. Syst. 2020, $177,102717$. [CrossRef]

18. Fröhlich, A.; Rice, B. Evaluation of Camelina sativa oil as a feedstock for biodiesel production. Ind. Crops Prod. 2005, 21, 25-31. [CrossRef]

19. Zanetti, F.; Alberghini, B.; Jeromela, A.M.; Grahovac, N.; Rajković, D.; Kiprovski, B.; Monti, A. Camelina, an ancient oilseed crop actively contributing to the rural renaissance in Europe. A review. Agron. Sustain. Dev. 2021, 41, 2. [CrossRef]

20. Eynck, C.; Falk, K.C. Camelina (Camelina sativa). In Biofuel Crops: Production, Physiology and Genetics; Singh, B., Ed.; CABI Publishing: Wallingford, UK, 2013; Volume 1845938852, pp. 369-391.

21. Francis, A.; Warwick, S.I. The biology of Canadian weeds. 142. Camelina alyssum (Mill.) Thell.; C. microcarpa Andrz. ex DC.; C. sativa (L.) Crantz. Can. J. Plant Sci. 2009, 89, 791-810. [CrossRef]

22. Righini, D.; Zanetti, F.; Martínez-Force, E.; Mandrioli, M.; Toschi, T.G.; Monti, A. Shifting sowing of camelina from spring to autumn enhances the oil quality for bio-based applications in response to temperature and seed carbon stock. Ind. Crops Prod. 2019, 137, 66-73. [CrossRef]

23. Soorni, J.; Kazemitabar, S.K.; Kahrizi, D.; Dehestani, A.; Bagheri, N. Genetic analysis of freezing tolerance in camelina [Camelina sativa (L.) Crantz] by diallel cross of winter and spring biotypes. Planta 2021, 253, 9. [CrossRef] [PubMed]

24. Liang, C.; Liu, X.; Yiu, S.-M.; Lim, B.L. De novo assembly and characterization of Camelina sativa transcriptome by paired-end sequencing. BMC Genom. 2013, 14, 146. [CrossRef] [PubMed]

25. Kagale, S.; Koh, C.; Nixon, J.; Bollina, V.; Clarke, W.E.; Tuteja, R.; Spillane, C.; Robinson, S.J.; Links, M.; Clarke, C.; et al. The emerging biofuel crop Camelina sativa retains a highly undifferentiated hexaploid genome structure. Nat. Commun. 2014, 5, 3706. [CrossRef]

26. Malik, M.R.; Tang, J.; Sharma, N.; Burkitt, C.; Ji, Y.; Mykytyshyn, M.; Bohmert-Tatarev, K.; Peoples, O.; Snell, K.D. Camelina sativa, an oilseed at the nexus between model system and commercial crop. Plant Cell Rep. 2018, 37, 1367-1381. [CrossRef] [PubMed]

27. Mandáková, T.; Pouch, M.; Brock, J.R.; Al-Shehbaz, I.A.; Lysak, M.A. Origin and Evolution of Diploid and Allopolyploid Camelina Genomes was Accompanied by Chromosome Shattering. Plant Cell 2019, 31, 2596-2612. [CrossRef]

28. Nguyen, H.T.; Silva, J.E.; Podicheti, R.; Macrander, J.; Yang, W.; Nazarenus, T.J.; Nam, J.-W.; Jaworski, J.G.; Lu, C.; Scheffler, B.E.; et al. Camelina seed transcriptome: A tool for meal and oil improvement and translational research. Plant Biotechnol. J. 2013, 11, 759-769. [CrossRef]

29. Shahadati-Moghaddam, Z.; Hosseini, A.; Soorni, J.; Trojak-Goluch, A. Development of tobacco (Nicotiana tabacum L.) doubled haploid lines resistant topotato virus Y0. Indian J. Genet. 2016, 76, 333-340. [CrossRef]

30. Ferrie, A.M.R.; Bethune, T.D. A microspore embryogenesis protocol for Camelina sativa, a multi-use crop. Plant Cell Tissue Organ Cult. (PCTOC) 2011, 106, 495-501. [CrossRef]

31. Soorni, J.; Kazemitabar, S.K.; Kahrizi, D.; Dehestani, A.; Bagheri, N. Screening of camelina (Camelina sativa L.) doubled haploid lines for freezing tolerance in the seedling stage. Genetika 2017, 49, 173-181. [CrossRef]

32. Berti, M.; Wilckens, R.; Fischer, S.; Solis, A.; Johnson, B. Seeding date influence on camelina seed yield, yield components, and oil content in Chile. Ind. Crops Prod. 2011, 34, 1358-1365. [CrossRef]

33. Anderson, J.V.; Wittenberg, A.; Li, H.; Berti, M.T. High throughput phenotyping of Camelina sativa seeds for crude protein, total oil, and fatty acids profile by near infrared spectroscopy. Ind. Crops Prod. 2019, 137, 501-507. [CrossRef]

34. Wittenberg, A.; Anderson, J.V.; Berti, M.T. Crop growth and productivity of winter camelina in response to sowing date in the northwestern Corn Belt of the USA. Ind. Crops Prod. 2020, 158, 113036. [CrossRef] 
35. Burgueño, J.; Crossa, J.; Rodríguez, F.; Yeater, K.M. Augmented designs-experimental designs in which all treatments are not replicated. In Applied Statistics in Agricultural, Biological, and Environmental Sciences; Glaz, B., Yeater, K.M., Eds.; John Wiley \& Sons: Hoboken, NJ, USA, 2018; pp. 345-370. [CrossRef]

36. Piepho, H.; Williams, E.R. Augmented Row-Column Designs for a Small Number of Checks. Agron. J. 2016, $108,2256-2262$. [CrossRef]

37. Federer, W.T. Augmented (or hoonuiaku) designs. Hawaii. Sugar Plant. Rec. 1956, 55, 191-208.

38. Scott, R.A.; Milliken, G.A. A SAS Program for Analyzing Augmented Randomized Complete-Block Designs. Crop Sci. 1993, 33, 865-867. [CrossRef]

39. Federer, W.T.; Reynolds, M.; Crossa, J. Combining Results from Augmented Designs over Sites. Agron. J. 2001, 93, 389-395. [CrossRef]

40. Haines, L.M. Augmented Block Designs for Unreplicated Trials. J. Agric. Biol. Environ. Stat. 2021, 26, 409-427. [CrossRef]

41. Aravind, J.; MukeshSankar, S.; Wankhede, D.P.; Kaur, V. Augmented RCBD: Analysis of Augmented Randomised Complete Block Designs. R Package Version 0.1.2.9000. 2020. Available online: https:/ /www.aravind-j.github.io/augmentedRCBD/https: / / cran.r-project.org / package=augmentedRCBD (accessed on 2 March 2019).

42. Neupane, D.; Solomon, J.K.Q.; Mclennon, E.; Davison, J.; Lawry, T. Sowing date and sowing method influence on camelina cultivars grain yield, oil concentration, and biodiesel production. Food Energy Secur. 2019, 8, e00166. [CrossRef]

43. Bansal, G.; Zhou, W.; Barlow, P.J.; Lo, H.-L.; Neo, F.-L. Performance of palm olein in repeated deep frying and controlled heating processes. Food Chem. 2010, 121, 338-347. [CrossRef]

44. López-Martínez, J.C.; Campra-Madrid, P.; Guil-Guerrero, J.L. $\gamma$-Linolenic acid enrichment from Borago officinalis and Echium fastuosum seed oils and fatty acids by low temperature crystallization. J. Biosci. Bioeng. 2004, 97, 294-298. [CrossRef]

45. Lepage, G.; Roy, C.C. Improved recovery of fatty acid through direct transesterification without prior extraction or purification. J. Lipid Res. 1984, 25, 1391-1396. [CrossRef]

46. AOCS. Nitrogen-Ammonia-Protein, Modified Kjeldahl Method; AOCS Recommended Practice Ba 4a-38/Ba 4b-87; AOCS: Champaign, IL, USA, 1987; p. 2.

47. Čanak, P.; Jeromela, A.M.; Vujošević, B.; Kiprovski, B.; Mitrović, B.; Alberghini, B.; Facciolla, E.; Monti, A.; Zanetti, F. Is Drought Stress Tolerance Affected by Biotypes and Seed Size in the Emerging Oilseed Crop Camelina? Agronomy 2020, 10, 1856. [CrossRef]

48. Zanetti, F.; Gesch, R.W.; Walia, M.K.; Johnson, J.M.; Monti, A. Winter camelina root characteristics and yield performance under contrasting environmental conditions. Field Crops Res. 2020, 252, 107794. [CrossRef]

49. Leclère, M.; Lorent, A.-R.; Jeuffroy, M.-H.; Butier, A.; Chatain, C.; Loyce, C. Diagnosis of camelina seed yield and quality across an on-farm experimental network. Eur. J. Agron. 2020, 122, 126190. [CrossRef]

50. Kurasiak-Popowska, D.; Tomkowiak, A.; Człopińska, M.; Bocianowski, J.; Weigt, D.; Nawracała, J. Analysis of yield and genetic similarity of Polish and Ukrainian Camelina sativa genotypes. Ind. Crops Prod. 2018, 123, 667-675. [CrossRef]

51. Załuski, D.; Tworkowski, J.; Krzyżaniak, M.; Stolarski, M.J.; Kwiatkowski, J. The Characterization of 10 Spring Camelina Genotypes Grown in Environmental Conditions in North-Eastern Poland. Agronomy 2020, 10, 64. [CrossRef]

52. Allen, B.L.; Vigil, M.F.; Jabro, J.D. Camelina Growing Degree Hour and Base Temperature Requirements. Agron. J. 2014, 106, 940-944. [CrossRef]

53. Obeng, E.; Obour, A.K.; Nelson, N.O.; Moreno, J.A.; Ciampitti, I.A.; Wang, D.; Durrett, T.P. Seed yield and oil quality as affected by Camelina cultivar and planting date. J. Crop Improv. 2019, 33, 202-222. [CrossRef]

54. Kurasiak-Popowska, D.; Stuper-Szablewska, K. The phytochemical quality of Camelina sativa seed and oil. Acta Agric. Scand. Sect. B Plant Soil Sci. 2019, 70, 39-47. [CrossRef]

55. Kurasiak-Popowska, D.; Graczyk, M.; Przybylska-Balcerek, A.; Stuper-Szablewska, K. Influence of variety and weather conditions on fatty acid composition of winter and spring Camelina sativa varieties in Poland. Eur. Food Res. Technol. 2021, 247, 465-473. [CrossRef]

56. Gesch, R.W.; Archer, D.W.; Berti, M.T. Dual Cropping Winter Camelina with Soybean in the Northern Corn Belt. Agron. J. 2014, 106, 1735-1745. [CrossRef]

57. Sydney, E.B.; Sydney, A.C.N.; de Carvalho, J.C.; Soccol, C.R. Microalgal strain selection for biofuel production. In Biomass, Biofuels and Biochemicals: Biofuels from Algae; Panday, A., Chang, J.S., Soccol, C.R., Lee, D.J., Chisti, Y., Elsevier, B.V., Eds.; Elsevier: Amsterdam, The Netherlands, 2019; pp. 59-66. [CrossRef]

58. Luo, Z.; Brock, J.; Dyer, J.M.; Kutchan, T.; Schachtman, D.; Augustin, M.; Ge, Y.; Fahlgren, N.; Abdel-Haleem, H. Genetic Diversity and Population Structure of a Camelina sativa Spring Panel. Front. Plant Sci. 2019, 10, 184. [CrossRef] [PubMed]

59. Zubr, J. Qualitative variation of Camelina sativa seed from different locations. Ind. Crops Prod. 2003, 17, 161-169. [CrossRef]

60. Wittenberg, A.; Anderson, J.V.; Berti, M.T. Winter and summer annual biotypes of camelina have different morphology and seed characteristics. Ind. Crops Prod. 2019, 135, 230-237. [CrossRef]

61. Augustin, J.M.; Brock, J.R.; Augustin, M.M.; Wellinghoff, R.L.; Shipp, M.; Higashi, Y.; Kumssa, T.T.; Cahoon, E.B.; Kutchan, T.M. Field performance of terpene-producing Camelina sativa. Ind. Crops Prod. 2019, 136, 50-58. [CrossRef]

62. Stefanoni, W.; Latterini, F.; Ruiz, J.; Bergonzoli, S.; Palmieri, N.; Pari, L. Assessing the Camelina (Camelina sativa (L.) Crantz) Seed Harvesting Using a Combine Harvester: A Case-Study on the Assessment of Work Performance and Seed Loss. Sustainability 2020, 13, 195. [CrossRef] 